\title{
White Supremacy and the Future of Liberal Democracy: The Case of the Nordic Resistance Movement
}

\section{Ida Oesteraas ${ }^{a}$}

aOld Dominion University, Norfolk, VA, USA

\section{ABSTRACT}

In 2015, the largest neo-Nazi organization in Scandinavia, The Nordic Resistance Movement (NRM) registered as a political party and entered electoral politics in Sweden. Utilizing qualitative content analysis, the current work explores changes in NRM's rhetoric from before the party entered politics in 2010 and five years later in 2018. Focus centers on NRM's ideology, what or whom they frame as their threat, and their suggested solutions for constructed problems. Results show fascist rhetoric in both time periods. An argument is made that there is no actual moderation in NRM's politics by liberal democracy. Rather, far-right extremism is a threat to liberal democracy, as we know it. Implications of the growth of the far-right, and the future of liberal democracy are discussed.
JQCJC "Qualitative Criminology," (2022)

Vol. 11, Iss. 2, 211-232

ARTICLE HISTORY

Received 8/21/2021

Accepted 9/27/2021

\section{KEYWORDS}

Nordic resistance movement, Sweden, liberal democracy, qualitative content analysis

Liberal democratic values are essential in an ever-changing world where challenges such as migration, the COVID 19-pandemic, and the rise of the far-right continue to impact many democracies. According to Mudde and Kaltwasser (2012, p. 13), liberal democracy is "a system characterized not only by free and fair elections, popular sovereignty, and majority rule, but also by the constitutional protection of minority rights." In other words, liberal democracy is a complex form of government rooted in political equality, which indicates that the majority cannot deprive the minority of its political rights. A strong liberal democracy has the potential to moderate extremist political ideas and is pivotal in fighting far-right political agendas (Bellamy, 2002; Lukes, 2004; Schain et al., 2002).

Valued democratic principles are under threat as far-right populist groups arise (Cox, 2018; Halikiopoulou et al., 2013; Traverso, 2019). By arguing for nationalism, antiimmigrant incentives, and other far-right master frames, far-right groups that enter the electoral field threaten liberal democracy as they attempt to move away from established democratic values. We can see evidence of such developments in many European

DOI: https://doi.org/10.21428/88de04a1.bd37be63 
countries. For instance, in Hungary, the far-right, anti-immigrant party Jobbik has focused its anti-Roma and anti-minority stances to gain significant support (Pirro, 2019). In France, the anti-immigrant National Rally has for years maintained its strong opposition to the Euro while it has placed great emphasis on blaming the European Union (EU) for mass immigration. In 2019, Le Pen's party gained the most votes in France's election to the European Parliament, showing that the far-right rises, yet again (Humphries \& Sebastian, 2019). Similarly, in Poland, the ultra-nationalist and anti-pluralist party PiS, has in the past five years, used its anti-EU incentives and Catholicism to gain popularity (Greven, 2016). By using anti-EU rhetoric and religion as catalysts to gain votes, PiS' strategy adds to the pool of far-right parties that are gaining legitimacy within the electoral field in European democracies.

With the rise of far-right parties, liberal democracy will either aid the process in moderating extremist ideas or the far-right will mask their identity in exchange, thus contribute to changing the nature of democracy. The current work investigates the role of liberal democracy in mitigating extremist politics. To that end, it asks two questions: 1) Does entering the parliamentary democratic process serve to moderate extremist views? 2) Did the rhetoric of the Nordic Resistance Movement (NRM) become more moderate once it entered electoral politics in Sweden? By analyzing posts from NRM's official website, the current qualitative content analysis shows no significant moderation of NRM's rhetoric, despite entering the electoral field. Implications for these findings for future research and public policy are discussed.

Historically, far-right extremist organizations in Scandinavia have been characterized as fringe groups and have been unable to establish legitimacy in society and politics (Lööw, 2019). In Scandinavia, such extremist groups were short-lived because they endured a one-sided focus on anti-immigration and failed to account for other political agendas. Contrasting this is the Nordic Resistance Movement (NRM), the largest far-right extremist organization in Scandinavia today (Kølvraa, 2019). In 2015, NRM's Swedish chapter registered as a political party and entered electoral politics. According to its party program, NRM is pro-nation state, where the goal is the creation of a state consisting of only Nordic (Germanic) people. Furthermore, NRM is anti-democratic and enforces authoritarian rule. NRM also denies ethnicities other than the Nordic while pushing eugenics politics, arguing that the Nordic race is superior (The Nordic Resistance Movement, 2016).

In 2014, one of NRM's key members, Pär Öberg, was elected as a write-in candidate for the far-right populist Sweden Democrats (SD) in the local election of the Swedish town, Ludvika (Habul, 2014). This development is believed to be the main motivation behind the NRM entering the electoral field. Starting as a niche organization, 
the decision to enter politics shifted NRM from being an external organization to becoming part of electoral politics. Despite NRM entering politics, the party does not appear to have made significant political gains in Sweden or Scandinavia as a whole (Fagge, 2016). The party is, however, viewed as a significant threat to security and democracy. In early 2020 , congress introduced H.R. 884, "Recognizing the global threat transnational white supremacist extremism presents to America and its interests" where the Nordic Resistance Movement was included in the U.S. Department of States' foreign terrorist organization list (116 Cong., 2020).

To gain traction in the electoral field, far-right extremist parties must change their rhetoric to fit within the frames of liberal democracy (Halikiopoulou et al., 2013). Researchers have examined the success of European radical right parties as they entered electoral politics in their respective countries. Essentially, the argument is made that far-right parties need to change their rhetoric to "fit" within the frames of electoral politics. For instance, the "nation state" and "nationalism" are central themes in far-right party programs but are themes parties aim to alleviate when entering the electoral field. Yet, this presents a hypothetical dilemma in that far-right parties may be masking their discourse to gain traction within the electoral field and in society.

NRM's ideals of race superiority as well as their suggestions of removing immigrants from Nordic countries opposes the ideals widely valued throughout European democracies. If we pair NRM's opposition to established democratic values along with their admiration of 1930's Europe, groupings of far-right extremists pose a real threat to liberal democracy as we know it. Given the increasingly interconnectedness of the world, it is pivotal to examine factors that may threaten our ability to function together within societies. By examining NRM we can shed light on recent developments in European politics, which can help illuminate the future of liberal democracy around the globe.

\section{Far-Right Discourses: Populism, Fascism, Nationalism}

Four bodies of literature informed the arguments of the study. The literatures of right-wing populism, fascism, and nationalism as it relates to the Nordic Resistance Movement (NRM) illuminate how these ideologies can be attractive to ordinary people and contribute to increased votes and changes in democracies. Contradicting these three literatures is pluralism, a concept central in liberal democracies that theoretically provides a solution to how extreme ideas can be mitigated.

The meaning of populism depends on the direction of political thought as right/conservative or left/liberal. Scholars argue that the most common denominator of far-right populistic parties is their exclusionist, ethno-nationalist notion of citizenship, 
which is usually reflected in the saying "our own people first" (Betz, 2004; Rydgren, 2005). The incentive indicates that a given nation should only be inhabited and enjoyed by those native to the country, and that others threaten this idea. NRM's rhetoric often refers to the creation of a nation state excluding people other than the Nordic race. This not only causes separations between groups in society where some belong and others do not, but it also contributes to a false incentive behind the construction of groups in society as the enemy.

The essence of fascism is to be found in the concept's intellectual ideas rooted in racial nationalism or antisemitic stereotypes (Allardyce, 1979; Linz \& Linz, 2000; Strømmen, 2008). Some posit that every proclaimed fascist organization has, at some point, drawn inspiration from German or Italian fascist parties (Strømmen, 2008). Perhaps the most direct example of this is when fringe organizations are inspired by historical fascist rhetoric, thus using Nazi or fascist symbolism as part of their political agenda. German Nazism has shaped NRM specifically in terms of extreme nationalism and cultural superiority of the Nordic peoples. With its charismatic totalitarian nature, Nazism rejected liberalism, democracy, human rights, and international cooperation (Nyomarkay, 1967), which are all essential aspects that are valued in liberal democracies.

Nationalistic ideas are often represented as part of far-right rhetoric. Anderson (2013, p. 1) defines nationalism as "an expression of certain straightforward ideas, which provide a framework for political life." Nationalism's most basic conceptualization then, is that only a selection of people belongs to a national group, further suggesting that socially constructed others do not belong. Thus, the notion of homogeneity is central, as well as the idea that "our nation" surpasses all other nations. Nationalism becomes especially challenging when far-right parties blame others as the major cause of social instability (Rydgren, 2003). For instance, ideas rooted in white nationalism have become legitimized as part of the majority population's perceptions of others (Ekman, 2018; Rydgren, 2003).

One study focused on how political parties use far-right discourses to construct false narratives around rumors of criminal refugees (Kreis, 2017). Ultimately, such political initiatives contribute to placing certain individuals in groups that "do not belong" in society. However, such notions do not always depict themselves in upfront racism and exclusionist behavior. Often, it is the sense of togetherness and the construction of the people (e.g., white and Nordic) that creates the connection to both nationalism and racism. Therefore, this discussion interacts with the conversation regarding populist rhetoric and the construction of others, but also with fascist intellectual content where racial superiority is an important element. 
"Qualitative Criminology"

\section{Pluralism}

Pluralism functions as a contrast to far-right populism, fascism, and nationalism. A pluralist perspective embraces a democratic equilibrium between independent parts of society where the goal is always compromise. According to a pluralist view, people become mobilized politically and ideologically rather than organized due to their ethnic and cultural lines (Máiz \& Requejo, 2004). This not only furthers peoples interests as a cohesive group of individuals, but also promotes collective interests. Thus, a pluralist society aims not only to create fewer disparities between people, but also to promote opportunity and equality, so that all individuals are valued in society. Thus, the main idea is to create representation of all parts in society, despite differences.

NRM is opposed to various groups in society. For one, the party opposes minority populations (populism) and suggests that immigrants and individuals of non-Nordic descent are not welcome and should leave Sweden (nationalism). Second, NRM's political agenda frequently opposes current governmental leadership as the party blames

previous and current government coalitions to be responsible for Sweden's present political and societal situation (fascism). These ideas suggest that minorities, such as immigrants of non-Nordic descent, are not valued citizens, while they also propose that non-Nordic individuals do not belong in the Nordic countries or in parliament (fascism). Thus, by preventing minorities and constructed others to partake in societal processes, NRM opposes the central ideals of the pluralist perspective.

\section{Method}

The current work explores the effects that far-right extremism might have on the nature of liberal democracy. More specifically, it focuses on how the rhetoric of the Nordic Resistance Movement (NRM) changed from before and after entering politics to examine if the electoral field serves to moderate extremist views. NRM entered Swedish politics in 2015, so this year served as the starting point of the study (see figure below). Three months leading up to the 2010 Swedish election (July-September) were chosen to account for the "before-politics" period. Thus, the "after-politics" period was the three months (July-September) leading up to the Swedish election in 2018. The months of JulySeptember were selected because they 1 ) represented the three months leading up to the elections in September 2010 and 2018 and 2) had an increase in the total number of posts published when compared to the preceding years, 2009 and 2017, respectively.

This study relies on a qualitative content analysis. The method was inductive in nature, and it focused on NRM's communicated content. To analyze NRM's rhetoric, posts published by NRM leadership, members, and guest writers were selected from 
NRM's official website, nordfront.se, which is likely the dominant platform for extremist ideas in Scandinavia (Kølvraa, 2019). A total of 169 posts were analyzed ( $n=70$ posts from July-September 2010 and $n=99$ from July-September 2018).

Figure 1: Election Timeline

2010

Election 1(before)
$<2015>$

Est. political party
2018

Election 2 (after)

\section{Application}

To examine the posts from 2018, cluster sampling was first used to narrow the sample (Babbie, 2020). Then, a random selection of posts was ensured using an online generator from random.org. The total number of posts depended on the year, but July-September 2018 produced a total of 2095, and for 2010 the total number of posts corresponded to 173. In 2018, cluster sampling was used to select 99 posts, which was further divided by three, corresponding to July, August, and September ( $n=33$ posts/month). To demonstrate this process, July 2018 contained a total of 565 posts, and 33 numbers were randomly selected via the integer generator. As the 33 numbers were selected, the corresponding posts were found within the July 2018 archive at nordfront.se. For instance, one of the randomized numbers was 27. Located within the July 2018 archive, post number 27 was found on page three.

Due to a shortage of posts from July-September 2010, the original plan of cluster sampling and random selection of posts in 2010 was not possible. Therefore, all posts (70) that consisted of more than 100 words were selected as part of the sample population in 2010. As the study aimed to analyze NRM's rhetoric, posts such as short announcements or demonstration updates ( $<100$ words) were not included as part of the sample in either 2010 or 2018. In 2018, random selection via the online number generator was initiated until a post with more than 100 words was located.

To guide the research, three questions regarding NRM were asked; 1) who are NRM? 2) what or who are NRM presenting as the threat? and 3) what are their suggested solutions moving forward? Given the purpose of the study in analyzing NRM's rhetoric, the communication from the posts were coded conceptually, which is a common procedure in qualitative content analysis (Altheide, 1987; Elo \& Kyngäs, 2008; Krippendorff, 2018; White \& Marsh, 2006). Conceptual coding allows for a close and 
interactive process, which aid in developing significant concepts and patterns (Creswell \& Poth, 2016; White \& Marsh, 2006). To start the coding process, all selected posts were printed and stored in a folder to separate the different posts by month and year. Then, while reading the posts, color coding was used to distinguish between concepts that fit within each of the three questions. For instance, in relation to question 1, wording such as "we are" and "as National Socialists," was used to ensure its place within the first question; "who are NRM?" Finally, concepts were placed within categories pertaining to the three questions relating to NRM. The concepts that occurred most frequently throughout the analysis were presented as main themes within each category. To ensure validity of the findings, the coding process was repeated multiple times before the final themes within each category was reviewed and confirmed by a fellow faculty member.

\section{Findings}

To account for a potential change in NRM's rhetoric before they entered electoral politics (2010) and after (2018), three topics guided the research: NRM's description of themselves, their perceived enemies, and their suggested solutions for perceived problems. The following section describes the findings from each of these categories. Salient examples from both 2010 and 2018 of each of these categories is included. To end, a comparison between the two time periods is presented.

\section{0 vs 2018-NRM's Description of Themselves}

In the first section, the goal is to discuss the way in which NRM describe themselves. In 2010, three themes stood out: "National Socialists," "patriots," and "revolutionary." Few changes in NRM's description of themselves are seen in 2018 as the party generally define themselves as "superior Nationalist Socialists," and "revolutionary."

National Socialists

In 2010, NRM describes themselves as National Socialists and emphasized the relevance of national solidarity to the reader. In a post about Göran Oredsson (leader of the neoNazi political party in Sweden-the Nordic Realm Party), NRM communicates the following,

By establishing the Nordic Realm Party and to declare National Socialism as its ideology, Oredsson fought to save Swedish and Nordic National Socialism. The fight was challenging, especially against those who value harmonization, when they try to imitate democracy - those who don't see a problem in collaborating with 
Jews, the white races' ultimate enemy ... Heil and thanks to Oredsson! (En nationalsocialist ur tiden, 2nd of July, 2010, number 45).

Here, NRM is celebrating the Swedish neo-Nazi leader Oredsson by crowning him the ultimate Swedish anti-Semitic hero. By glorifying Oredsson, NRM are clearly making the point that they too, are National Socialists who are looking for national solidarity. The way NRM degrades the idea of harmonization stands in opposition to pluralist ideas, where equilibrium between independent parts is crucial in decision-making (Máiz \& Requejo, 2004). Additionally, by the direct inclusion of the Nazi salute, "heil," NRM is clearly referring to Nazi symbolism (Strømmen, 2008). Just like Nazism was the German version of fascism, National Socialism as defined by NRM can be understood as the Swedish version of the concept.

Patriots

NRM describe themselves as "Swedes" or "Nordic." This notion is, of course, in opposition to the social construction of others. To illustrate this idea, NRM states that,

Immigrants are ludicrous and denigrating. They are offending all Swedish generations that have helped build Sweden to reflect what it is today. For them to claim they are extremely important because of this demonstration is an example of what the future will hold if we keep inviting more of them into the country (Invandrare strejkade - Sverige stannade inte, September 16th, 2010, number 14).

By constructing a difference between 'us' (Swedes) and 'them' (immigrants), NRM contributes to the demonizing of immigrants while making the case that their presence in Sweden is unwanted (Wodak et al., 2013). These ideas connect to those of nativism, racism, and the construction of the "us vs. them" mentality, which are important ideas in nationalistic and fascist rhetoric (Swain, 2002).

\section{Revolutionary}

NRM also describe themselves as revolutionary. One of NRM's members wrote a post titled "Radicalism or compromise." In this post, he functions as NRM's spokesperson on the matter, as thoughts on NRM as a revolutionary organization are discussed. The author titles NRM as a "revolutionary organization" before describing the meaning behind being radical,

To be radical is to find the root issue, or root cause and further engage in action to change the current unwanted situation... we will do everything in our power to 
"Qualitative Criminology"

change the sick system we live in (Radikalism eller kompromiss, 17th of September, 2010, number 10).

According to this quote, NRM are looking to amend the current, unwanted situation by changing the system that they frame as "sick." The presented suggestions are all signs of revolutionary behavior and connect to Adolf Hitler's radical nature during Nazi Germany (Spender, 1978).

\section{Superior National Socialists}

Also in 2018, NRM's description of themselves as National Socialists is prevalent. By using language such as "Sweden is our country," "our people," "our race," where "our" refers to white individuals of ethnic Swedish origin, NRM's rhetoric connects to that of nationalism. Such notions of superiority correspond with NRM's description of themselves as superior National Socialists. In a post from August, NRM writes,

The law against ethnic groups is clearly made to prevent Swedes moral and practical right to defend our own people in our motherland ... Ethnic Swedes are the ones that suffer through daily persecution, and we are especially affected by rape, threat, robbery, assault, and murder ... Due to Anti-Swedish lawmaking, we are the "legitimate prey" ... How are we supposed to react to this when all people are equal? (Är du svensk ska du tåla mer! 15th of August, 2018, number 434).

By NRM's frequent use of exclusionist and National Socialist rhetoric, there is not much evidence to point to that NRM believe all people are equal. By using certain language that communicates the idea that Nordic people are superior, NRM makes the point that white, ethnic Swedes are more valuable than any other racial group. Therefore, NRM's communication of "all people are equal" appears out of place as it contradicts their belief of the Nordic race as superior.

Revolutionary

NRM further describe themselves as part of "the people" as a "fight group," while placing great emphasis on this collective identity as revolutionary. The following communicates this point,

Our people are soon replaced with ethnic others originating from all over the world. Trips, new cars, new cell phones and trash-TV; does it even matter since our people are becoming extinct? No, disconnect yourself from such examples of 
materialistic hell and become a resistance man or woman already (Antiglobalism i Trelleborgs kommun, 26th of September, 2018, number 89).

Such communication clarifies that NRM is opposed to developments that result from globalization, as presented in their party platform (The Nordic Resistance Movement, 2016). As NRM describe themselves to be part of a "fight group" composed of national socialists, they are revolutionary in the way they would seek drastic change through violence. Nazi Germany was also revolutionary when Hitler gained the majority power in the Reichstag. This observation connects to the literature on Nazism in that NRM seems to operate outside the parliamentary democratic process in hopes of achieving their revolutionary social, and governmental goals (Spender, 1978).

\section{0 vs. 2018-NRM's Description of Their Enemies}

In the second section, the aim is to understand what or whom NRM describe as their enemies. In 2010, four themes stood out; the media, the current political system, Jews, and "others." In 2018, two themes were salient: Jews, and the racial "other."

The Media

In 2010, one of NRM's perceived enemies is the media. For example, rhetoric framing the media as "corrupt" is prevalent in much of their communicated content. One example is found in a post from July 2010. Here, NRM communicates that the media is "unjust and corrupted" as they share,

[I]t (the media) is blind because it is against everything they identify as for Sweden. Those that want to fight for Sweden and non-leniency in the media must fight back in the ongoing propaganda war ... when it comes to security, we can never believe in the corrupt system, only ourselves (Skådeplats Tranemo, 13th of July, number 30).

Here, NRM are using words such as "ourselves" and "we" to describe NRM and its followers, namely white, Nordic, and ethnic Swedes. It is apparent that this rhetoric has clear ties to nationalistic, fascist, and right-wing populist rhetoric because it aims to strengthen the sense of racial solidarity while continuously uniting supporters to NRM's vision of the nation (Hainsworth, 2008). 
"Qualitative Criminology"

\section{Current Political System}

NRM also frames the current political system as the enemy. For example, NRM engages exclusionist opinions on current initiatives related to the restriction of the traditional Muslim garment, the burqa. NRM communicates the following regarding the Sweden Democrats' (SD) initiative,

The burqa initiative is only following a mainstreamed European trend. It is trying to avoid reforming the hopeless political system that was established after $1945 \ldots$ With such arrangements, one will only force integration. For every Swede and European, this is a nightmare (Burkaförbud? Nej tack!, 5th of August, 2010, number 70).

For NRM, the political system established in the aftermath of 1945 is inadequate. This notion aligns with beliefs of other far-right extreme nationalistic organizations, which indicates NRM's admiration of such politics. NRM's frequently blames communism as the unwanted political system standing in stark opposition to NRM's National Socialist values. The reference to viewing communism as the enemy connects to historical observations of communism as Nazism's most immediate rival, and is significant in the discussion over NRM's enemies (Evans, 2006).

\section{Jews}

NRM also depicts those of Jewish descent as the ultimate enemy. In one post, the author claims that the true nature of Swedish nationalism cannot be understood without comprehending the "Jew-problem." Indeed, Hitler's Nazi politics aimed to gather racially superior Germans into a tightly knit community where racial harmony was the goal. To accomplish such racial harmony, it was necessary to exclude people of "inferior" blood, a plan understood to be the Nazi solution to the so-called "Jewish problem" (Spielvogel \& Redles, 2020).

In one of the posts this year, NRM cites Lars Dencik, who is described as a "Jew" when he says: 'Swedish nationalism is threatening the humanistic, liberal, and social world'. NRM responds to this with a statement arguing that Dencik, together with other Jewish scholars, are using "double-speak and talk with forked tongues" when fronting views that do not align with NRM's National Socialism. Such communication specifies that NRM do not deem National Socialism as threatening to liberal democracy and are statements that connect to fascist, right wing populist, and extreme nationalistic rhetoric, which in turn are concepts that exist in opposition to those of pluralism (Galston, 2018; Lijphart, 1975). 
"Others"

Posts by NRM also showed the party's clear intention to build a certain "us vs. them" distinction within Sweden. As noted previously, far-right populism tends to construct ingroup and out-group politics (Hameleers, 2019). Findings indicate that this also applies for NRM in the way they depict immigrants as a threat to Sweden's ethnic solidarity. For instance, NRM provide an alternative explanation when describing why the general Swedish population has become increasingly positive to immigration,

Demker's research has become popular among mass media and is supporting the ongoing multiculturalism in Sweden. If Demker's numbers are true, NRM finds it important to present another reality. In the fall of 2009, 12 percent of Swedes would not approve of individuals from other world corners being part of one's family through marriage. In 1993, the percentage was 25. Such numbers prove that the indoctrination of Swedes has taken place and that more people have lost their ability to think critically ... As such, Demker's research might be distorted propaganda! (Hallandsposten förespråkar folkmord, 24th of August, 2010, number 17).

With this message, NRM seems to not only be opposed to multiculturalism, but also to constructed others that fall outside the category of ethnic Swedes. Research indicates that one's preconceived notion of fear can distort one's sense of what is right, and therefore compromises the democratic ideal of social justice as understood by a pluralist perspective (Maalouf, 2001). History has shown that rhetoric in accordance with NRM and the resulting hostility towards others have the potential to graduate to vicious forms of violence. This is particularly concerning given several NRM members have already engaged in violent behavior (Vergara \& Nilsson, 2016).

Jews

In 2018, NRM's rhetoric show significant antisemitic views. For instance, a discussion including American columnist Philip Giraldi concerns how the United States is failing to dismantle violence and terror in Israel. NRM communicates the following,

The news concerning Israel was deleted from the article a few hours later. This is just like when SVT in Sweden cut out news from their websites to avoid revealing people's identity ... That is especially if suspects of crimes are black Africans or Jews ... This is an example of how the media self-censors its news when something negative is written about others and Israel ... The U.S. contributes to the creation of scapegoats that look at themselves as superior Americans. In fact, 
using scapegoats is a prehistoric Jewish method to avoid taking responsibility for sins ... This idea is described in the Torah, one of the Jews' "Holy" Scriptures (Att mata monstret Israel, 20th of July, 2018, number 239).

In addition to the foregoing passage, NRM also states that "the richest donors are typically Jews ... With money, they buy their desired politics." Such messages by NRM not only contributes to our understanding of their view of Jews as inferior, but also feeds the illogical idea that Jews are responsible for societal downturns and corrupt political systems. As such, NRM's framing of Jews as the enemy builds upon the hostile views of Jews presented in fascist rhetoric from Nazi Germany (Alvarez \& Bachman, 2019).

The Racial Other

NRM also write about the racial other as explained earlier, which in addition to Jews, refers to immigrants, migrants, and refugees. Overall, NRM frame these groups of people to be violent, and in opposition to established Swedish values, and therefore posing a threat to traditional Swedish society. Although the current Swedish population consists mostly of ethnic Swedes, this group is never mentioned as violent by NRM. Rather, the description of "violent and brutal" is reserved exclusively for constructed racial others. An example of this idea is communicated in the following lead paragraph,

Multiculturalism. After all rape-cases got cleared in the end of May, another racial other is being framed as the suspect for yet another rape-case dated to the beginning of July (Ännu en våldtäkt i Boden, 13th of July, 2018, number 365).

It is worth noting that NRM included the alleged rapists' identification number, which is an addition that could potentially become a security issue for the individual. In this quote, NRM is blaming immigrants and the resulting multiculturalism to be the sole reason to why violent acts happen. Such rhetoric is closely connected to that of extreme nationalism and fascism in that the intrusion of others threatens established, idealized societal values (Ekman, 2018; Swain, 2002).

2010 vs 2018-NRM's Suggested Solutions

In 2010, NRM suggests a revolutionary solution to the current situation, namely the establishment of a "pan-Nordic Republic." In 2018, the idea of "stopping the invasion" stands out. 
Pan-Nordic Republic

In 2010, there remains much communication suggesting the creation of a pan-Nordic Republic, consisting of ethnic Nordic people only. The following quote illuminates NRM's suggested solution of a pan-Nordic Republic,

On the grounds of a National Socialist framework, The Nordic Resistance Movement wants a new process of state building. This means that today's political system needs to be revoked so that we can create room for an entirely reformed state. The new Nordic Republic will be made up of those that are part of the Nordic race ... our idea is that our Republic will be fairer and more useful for us as compared to any other political system that have previously existed in the North ... Everything will be done in harmony with Adolf Hitler's ideas (Om presidenter och monarker, 15th of July, 2010, number 22).

The quote is the words of a revolutionary, nationalistic, and hierarchical organization, which appears to be in strong opposition to the socially constructed others. In Sweden, there has been drastic changes in the demographic composition due to the influx of immigrants from African and middle eastern countries (Andersen, 2018). Depictions of racial superiority are often associated with white nationalism, which is a concept that is often connected to nativism. Importantly, nativism refers to the protecting the interest of native peoples while dismissing the safeties of those who are constructed, by the native population, as others (Alvarez \& Bachman, 2019). Findings also indicate that NRM promotes various other forms of exclusionist rhetoric as they encourage actions such as "the return of immigrants to their home countries," and "tearing down African culture projects." NRM then, are looking to create racial solidarity in a homogeneous Swedish society.

Stopping the Invasion

Increased globalization and higher levels of immigration tend to lead some people to become nostalgic over an idealized and illusory past. In 2018, NRM's solution is to stop the invasion of socially constructed others. We can see evidence of this idea from August when NRM write,

Vote for a free Sweden and a Nordic Union. Vote for ethnic solidarity, selfsufficiency, and a safe future. Vote for idealism and real people power! (Är du svensk ska du tåla mer!, 15th of August, 2018, number 434). 
As discussed previously, the idea of ethnic solidarity is one of NRM's main goals when creating a pan-Nordic Republic consisting of only Nordic people. This message is rooted in the notion of returning to an idealized Swedish Nation. The idea of returning to a romanticized notion of the past is not a newly developed idea. For instance, Nazi rhetoric highlighted the importance of returning to an idealized past — rhetoric used as a catalyst to generate emotional responses in ordinary people. In more recent times, we see former U.S. President Donald Trump communicate similar ideas when he uses rhetoric such as "make America great again" (Huber, 2016). With the suggested return to an idealized past, NRM's communication relates to right-wing populism, but also to fascist intellectual ideas (Galston, 2018; Hagen, 2004; Traverso, 2019).

\section{Summary of Findings}

In both time periods, NRM describe themselves as National Socialists, which is a narrative in line with Nazi rhetoric from the 1930-40's. NRM's descriptions of their enemies are similar in 2010 and 2018. For example, in depicting the red wave of communism and Jews as two of its enemies, NRM are using similar rhetoric as Hitler did during National Socialism in 1930's Germany. NRM's suggested solutions moving forward have also not changed throughout time. As discussed previously, results show that NRM wishes to create a pan-Nordic Republic consisting of only Nordic people, which are notions that resemble those of Nazi exclusionist and expansionist ideas. Combined, these findings show that NRM is using extreme forms of fascist rhetoric in both 2010 and 2018. In the case of NRM then, findings indicate that entering the parliamentary democratic process has not served to moderate the party's extremist stances. As a result of the lack of moderation in NRM's rhetoric, there is a chance that liberal democracy could be susceptible to extremist politics.

\section{On Fascist Infiltration in Democracies}

In theory, liberal democracy serves as a moderator in mitigating extremist politics (Bellamy, 2002; Lukes, 2004; Schain et al., 2002). However, this may only be true with evidence that demonstrates the mitigation of such politics. With no significant moderation, chances are liberal democracy does not work as theorized. Findings indicate that entering the parliamentary democratic process has in fact not served to mitigate the Nordic Resistance Movement's (NRM) extremist politics. As a result of the lack of moderation, there is a chance liberal democracy is vulnerable to extremist politics, today and in the future. The discussion below clarifies some of the implications that can follow from such an advance. 
One way to reduce the risk of fascist infiltration into the democratic system is that moderate parties could show an unwillingness to cooperate with far-right extremist parties. This could lead the extremist party to have limited power in governmental processes. The intersection of extremist parties' unwillingness to mitigate their politics, and mainstream parties' reluctance to cooperate with extremist parties, can lead the farright party to be overruled, ignored, or banned from the electoral field. Although it might be difficult to grasp the idea of letting extremist parties exist within the electoral field or in society in general, banning an extremist organization might, in some cases, lead extremist supporters to engage alliance elsewhere. For instance, members could radicalize further via online networks and consequently, cause harm to society. As we recall a past where far-right extremist parties went from fringe movements to leading political powers in Nazi Germany and Fascist Italy, we know that such developments, although manifested in different ways, can advance also today (Eley, 2013; Nyomarkay, 1967). As some would argue, history does not repeat itself, it simply rhymes.

Another possibility of reducing the risk of fascist infiltration in the democratic system can happen if moderate parties collaborate with the far-right. In a multi-party system, the moderate party can use the extremist party as a "safety net" to secure their own place in the coalition. In turn, cooperation on such bases might lead the far-right party to not have a say in political debate. This idea played out in a recent coalition change in electoral politics in Norway. In 2013, the far-right party Fremskrittspartiet (FrP), were accepted into a coalition with the conservative party, Høyre. However, FrP exited the coalition in early 2020 due to not being heard politically (Bentzrød, 2020). Although such party coalitions can lead far-right parties to have less political influence, as seen in the example of FrP, it may also be true that far-right parties gain more recognition as part of a coalition. However, in countries that employ a system characterized by proportionate representation in a multi-party system, political influence is divided amongst several political parties. Thus, far-right parties have the potential to advance to legislative seats because they can, together with other parties, establish governmental coalitions. It is when this happens that far-right parties threaten democracy because they, in their politics, attempt to move away from established democratic values.

Results from the failure of political participation to moderate fascist rhetoric is that moderate parties are drawn to rightward policy immersion. This could happen if moderate parties lose their voters to far-right parties. Such a potential development can lead moderate parties to question whether to adopt extremist stances to recover such losses. As various illiberal positions posed by the far-right are legitimized through such policy repositioning, a steady weakening of established core democratic values is possible. For example, the inclusions of one's own people and the exclusion of others is one of the most characteristic incentives enforced by far-right parties. For instance, anti-immigration 
policies may gain initial momentous support in times of economic hardship or threat of migration but has the potential to continue to be part of the new mainstream after the fact. We do not have to look far to find recent examples of such mainstreaming. For instance, the conservative political landscape in the U.S. has been gravely altered due to the mainstreamed spread of conspiracy theories that for instance, claim a stolen 2020 presidential election.

Failure to moderate extremist politics also means the possibility that exclusionist ideas such as the "us vs. them" mentality become part of the mainstream. Findings from the current study indicate that NRM uses the notion of ethnonationality to construct an ingroup and an out-group, respectively the people as contrasted by others. Here, the people are ethnic Swedes, and understood as the only individuals worthy of residing in Sweden. This finding further suggests that socially constructed others such as immigrants do not belong in society. As discussed earlier, white nationalistic rhetoric and the construction of others often entails the alleged corrupt and political elite, immigrants, and other minorities excluded from the people. Surely, such constructions of enemies are prevalent in NRM's rhetoric, but also when we look further at some of the oldest democracies in the world. In other words, this far-right discourse regarding the people is elitist and exclusionist as socially constructed others are, to different degrees, rejected from society. Such examples of extreme nationalism might lead to discursive aspects of discrimination, further leading similar discourses rooted in racism to become a natural and therefore acceptable reaction to the unwanted presence of others.

\section{Limitations}

There are several limitations of this study worth noting. First, since the study engaged an ethnographic content analysis, the analysis called for the possibility of differences in individual interpretation, which can yield varying results. Specifically, the observed meanings of the examined texts may differ, especially considering the researcher's positionality and potential biases (Babbie, 2020; Bernard \& Bernard, 2013). Second, in the process of conducting the research, challenges concerning the posts emerged. Specifically, the lack of total posts published in July and September 2010 caused disruption from the initial plan of selecting 33 posts from every month. Third, as the posts were translated from Swedish to English, the text may have lost nuances and meanings. As some sayings may have one specific denotation in Swedish, this may not translate to the same exact expressions when translated to English. However, since this study seeks to understand NRM's communicated content, the researcher aimed to translate the text by meaning, which is the goal of qualitative research. Due to the researcher's ability to read and understand Swedish, this limitation should be minor. 


\section{Implications for Research and Policy}

The findings of the study yield several implications for research and policy. The spread of global conspiracy theories such as QAnon, changes in perceived societal threats, as well as societal and economic hardship can lead the general population to adapt alternative views of reality rooted in far-right extremist ideologies. In relation to NRM, the party's leader Simon Lindberg, published in March 2020 on Nordfront.se, describing the party's aim to recruit members amidst the COVID-19 pandemic and economic hardships. Given NRM's lack of moderation, and the current polarized political landscape in many western democracies, future research should focus on NRM and other far-right groups' recruitment process before, during and after times of hardship to determine the potential growth of the far-right extreme. Recent violence incited by former president Donald Trump on the U.S. Capitol in January 2021 is one example that speaks to the current challenges in democracies, namely the mobilization of mistruth and extreme nationalism. Thus, it also becomes imperative to address whether extremist views such as those depicted in NRM's content are approaching the political and social mainstream across western democracies.

Given the increased online presence of the far-right, it is also pivotal to suggest policies aimed to deter the spread of extremism. We may look to Europe for inspiration to policies aimed at regulating extremist content online. In April 2021, the European Union (EU) passed a set of policies to regulate extremist content online. The initiative is said to be a reaction to the multitude of "lone wolf offender" attacks, coupled with the common understanding that the spread of radical ideologies and terrorist support material intensifies by online media outlets and often plays a fundamental part of the attack itself (Commission, 2020). Specifically, this law will force multinational tech companies such as Google, Facebook, and Twitter to remove terrorist content within an hour of being posted. As continued violent attacks on minority communities show, such hate speech is dangerous to the security of all individuals. Notwithstanding the importance of policy initiatives, above all else, there is a need for collective actions across ethnic identities to join an unrelenting cultural war against all manifestations of white supremacy.

\section{References}

Anderson, M. (2013). States and Nationalism in Europe since 1945. Routledge.

Andersen, H. M. (2018). Et flerkulturelt samfunn. En komparativ analyse av norsk og svensk integreringspolitikk som en toveis prosess (Master's thesis, The University of Bergen). 
Allardyce, G. (1979). What fascism is not: thoughts on the deflation of a concept. The American Historical Review, 84(2), 367-388.

Altheide, D. L. (1987). Reflections: Ethnographic content analysis. Qualitative sociology, 10(1), 65-77.

Alvarez, A., \& Bachman, R. D. (2019). Violence: The enduring problem. Sage Publications.

Babbie, E. R. (2020). The practice of social research. Cengage Learning.

Bellamy, R. (2002). Liberalism and pluralism: Towards a politics of compromise. Routledge.

Bentzrød, S. B. (2020, January 20). Disse grunnene oppgir Siv Jensen for hvorfor hun tar Frp ut av regjering. Aftenposten.

Bernard, H. R., \& Bernard, H. R. (2013). Social research methods: Qualitative and quantitative approaches. Sage.

Betz, H. G. (2004). The growing threat of the radical right. In Right-wing extremism in the twenty-first century (pp. 85-104). Routledge.

Commission, E. (2020). A Counter-Terrorism Agenda for the EU: Anticipate, Prevent, Protect, Respond (pp. 1-24, Rep.). Brussels: European Commission.

Cox, M. (2018). The rise of populism and the crisis of globalization: Brexit, Trump and beyond. In The Post Cold War World (pp. 239-247). Routledge.

Creswell, J. W., \& Poth, C. N. (2016). Qualitative inquiry and research design: Choosing among five approaches. Sage.

Ekman, M. (2018). Anti-refugee mobilization in social media: The case of soldiers of Odin. Social Media + Society, 4(1).

Eley, G. (2013). Nazism as Fascism: violence, ideology, and the ground of consent in Germany 1930-1945. Routledge.

Elo, S., \& Kyngäs, H. (2008). The qualitative content analysis process. Journal of advanced nursing, 62(1), 107-115. 
Evans, R. J. (2006). The third Reich in power (Vol. 2). Penguin.

Fagge, N. (2016, February 3). Exclusive: Neo-Nazis thugs warn of a 'year of violence' following attacks on child migrants at train station in Sweden. Daily Mail.

Galston, W. A. (2018). Anti-pluralism. Yale University Press.

Greven, T. (2016). The rise of right-wing populism in Europe and the United States. A Comparative Perspective [La emergencia del populismo de derechas en Europa y Estados Unidos. Una perspectiva comparada]. Friedrich Ebert Foundation, Washington DC Office, 1-8.

Habul, K. (2014, September 23). Nazist Kuppar in sig på SD-mandat i Ludvika. Aftonbladet.

Hainsworth, P. (2008). The extreme right in Europe. Routledge.

Hagen, J. (2004). The most German of towns: creating an ideal Nazi community in Rothenburg ob der Tauber. Annals of the Association of American Geographers, 94(1), 207-227.

Halikiopoulou, D., Mock, S., \& Vasilopoulou, S. (2013). The civic zeitgeist: nationalism and liberal values in the European radical right. Nations and nationalism, 19(1), 107-127.

Hameleers, M. (2019). Putting our own people first: the content and effects of online rightwing populist discourse surrounding the European refugee crisis. Mass Communication and Society, 22(6), 804-826.

Huber, L. P. (2016). Make America great again: Donald Trump, racist nativism and the virulent adherence to white supremecy amid US demographic change. Charleston $L$. Rev., 10, 215.

Humphries, H. E., \& Sebastian, S. R. P. (2019). Results of EU Parliamentary Elections 2019. EU Centre Background Brief 30 May 2019.

Kreis, R. (2017). \#refugeesnotwelcome: Anti-refugee discourse on Twitter. Discourse \& Communication, 11(5), 498-514.

Krippendorff, K. (2018). Content analysis: An introduction to its methodology. Sage publications. 
"Qualitative Criminology"

Kølvraa, C. (2019). Embodying 'the Nordic race': imaginaries of Viking heritage in the online communications of the Nordic Resistance Movement. Patterns of Prejudice, 53(3), 270-284.

Lijphart, A. (1975). The Politics of Accommodation: Pluralism and Democracy in the Netherlands. $2 d$ Ed. rev. University of California Press.

Linz, J. J., \& Linz, J. J. (2000). Totalitarian and authoritarian regimes. Lynne Rienner Publishers.

Lukes, S. (2004). Power: A radical view. Macmillan International Higher Education.

Lööw, H. (2019). Nazismen i sverige 1980-1999. Ordfront.

Maalouf, A. (2001). In the name of identity: Violence and the need to belong. Arcade Publishing.

Máiz, R., \& Requejo, F. (Eds.). (2004). Democracy, nationalism and multiculturalism (Vol. 14). Routledge.

Mudde, C., \& Kaltwasser, C. R. (Eds.). (2012). Populism in Europe and the Americas: Threat or corrective for democracy?. Cambridge University Press.

Nyomarkay, J. (1967). Charisma and factionalism in the Nazi Party. $U$ of Minnesota Press.

Pirro, A. L. (2019). Ballots and barricades enhanced: far-right 'movement parties' and movement-electoral interactions. Nations and nationalism, 25(3), 782-802.

Recognizing the global threat transnational white supremacist extremism presents to America and its interests, H.R. 884, 116 Cong. (2020).

Rydgren, J. (2005). Radical right-wing populism in Sweden and Denmark. In The Centre for the Study of European Politics and Society, 2005 Seminars.

Rydgren, J. (2003). Meso-level reasons for racism and xenophobia: Some converging and diverging effects of radical right populism in France and Sweden. European Journal of Social Theory, 6(1), 45-68. 
Schain, M., Zolberg, A., \& Hossay, P. (Eds.). (2002). Shadows over Europe: The development and impact of the extreme right in Western Europe. Springer.

Spender, S. (1978). The Thirties and after: poetry, politics, people (1933-75). Springer.

Spielvogel, J. J., \& Redles, D. (2020). Hitler and Nazi Germany: A History. Routledge.

Strømmen, Ø. (2008). Eurofascism. Lulu.com.

Swain, C. M. (2002). The new white nationalism in America: Its challenge to integration. Cambridge University Press.

The Nordic Resistance Movement (2016, September). Our Path - New Politics for a New Time. NF Forlag.

Traverso, E. (2019). The new faces of fascism: Populism and the far right. Verso Books.

Vergara, D., \& Nilsson, N. (2016, September 12). SÅ våldsamma är nazisterna i Nordiska Motståndsrörelsen. Expo.se.

White, M. D., \& Marsh, E. E. (2006). Content analysis: A flexible methodology. Library trends, 55(1), 22-45.

Wodak, R., KhosraviNik, M., \& Mral, B. (Eds.). (2013). Right-wing populism in Europe: Politics and discourse. A\&C Black.

\section{Contributor}

Ida Oesteraas is a doctoral researcher and teaching associate in the Department of Sociology and Criminal Justice at Old Dominion University, Virginia, United States. Her current main research interests concern right-wing extremism, social and racial issues, and changes in western democracies. 